\title{
ПЕДАГОГІЧНІ УМОВИ ВІЙСЬКОВО-ПРОФЕСІЙНОЇ ОРІЄНТАЦЇ̈ ЛІЦЕЇСТІВ ЗАКЛАДІВ СПЕЦІАЛІЗОВАНОЇ СЕРЕДНЬОЇ ОСВІТИ 3 ВІЙСЬКОВИМ ПРОФІЛЕМ
}

\author{
Василь Ягупов \\ доктор педагогічних наук, професор, \\ Національного університету оборони України імені Івана Черняховського \\ м. Київ, Україна \\ ORCID ID 0000-0002-8956-3170 \\ yagupow1957@gmail.com \\ Ксенія Єргідзей \\ здобувач, начальник науково-дослідної лабораторії, \\ Національний університет оборони України імені Івана Черняховського \\ м. Київ, Україна \\ ORCID ID 0000-0003-4634-133X \\ ergidzey@ukr.net
}

\begin{abstract}
Анотація. Стаття присвячена актуальній проблемі: військово-професійній орієнтації ліцеїстів закладів спеціалізованої середньої освіти 3 військовим профілем. Опрацьовані результати узагальнення висновків наукових праць учених, які розв'язують проблему військово-професійної орієнтації юнаків. Визначено основні педагогічні умови військовопрофесійної орієнтації ліцеїстів, до яких слід віднести військово-патріотичне виховання юнаків, формування цінностей і мотивації майбутньої військово-професійної діяльності в ліцеїстів, а також формування культури навчально-пізнавальної діяльності вихованців ліцеїв. У статті означені необхідні складові патріотичного виховання ліцеїста, визначені його види та форми, які доцільно використовувати в сучасних умовах в ліцеях. Розглянуто, що цінності є ключовим чинником військово-професійної орієнтації ліцеїстів, які є підвалиною їхньої мотиваційної сфери щодо майбутньої військово-професійної кар'єри.
\end{abstract}

Ключові слова: педагогічні умови; військово-професійна орієнтація; військовопатріотичне виховання; мотивація; цінності; навчально-пізнавальна діяльність.

Постановка проблеми. Зміни зовнішньополітичної орієнтації України внаслідок військової агресії з боку Російської Федерації та незаконних збройних формувань окремих районів Донецької та Луганської областей обумовили необхідність кардинального реформування воєнно-політичного життя країни, а саме: підвищення престижу армії і військових професій, посилення уваги до соціально-побутових умов військовослужбовців, модернізації та реформування військової освіти.

Сучасні тенденції в галузі освіти характеризуються підвищенням інтересу до патріотичного виховання молодого покоління, спробами повернути довіру молоді до служби в армії та військової професії. У зв'язку з чим актуального 
значення набувають проблеми формування військово-професійної орієнтації, спрямованості та військово-патріотичного виховання допризовної молоді, зокрема безпосередньо і ліцеїстів. Крім того, актуальність військово-професійної орієнтації ліцеїстів зумовлена об'єктивною необхідністю стосовно сьогоднішньої соціально-економічної ситуації та воєнно-політичної обстановки в країні, бо особливої значимості набуває готовність юнаків захищати інтереси України, представляти себе як громадянина і патріота, наявність позитивного ставлення до Збройних Сил України та служби в них.

Аналіз останніх досліджень і публікацій. Аналіз та узагальнення психолого-педагогічних джерел показує, що різні аспекти проблеми професійної орієнтації молоді до служби в армії недостатньо перебувають у центрі наукових інтересів учених, практичних педагогів, психологів, керівників освітніх закладів. Так, дослідженню проблеми професійної орієнтації учнівської молоді на військові професії присвячено роботи Н. Аксьонова, А. Афанасьєва, В. Артеменка, А. Борисовського, І. Глазунової, В. Ковальського, О. Комарова, С. Мотики, В. Микитюка, М. Нещадима, Л. Чернишова, В. Чудного, В. Ягупова. Різні психологічні аспекти спрямованості особистості досліджені в роботах Л. Божовіч， О. Ковальова， О. Леонтьєва， К. Платонова， А. Рудика, які обгрунтовують їі як елемент мотиваційної сфери особистості поряд із потребами.

У педагогічному плані проблема спрямованості особистості досліджується А. Алексюком, А. Дьоміним, А. Денисенком, М. Тимчиком, Л. Чупрій, а iї професійно орієнтований аспект - В. Алфімовою, І. Берестецькою, В. Бобровим, Г. Воликом, Г. Хмельницькою та ін. Проблема військово-професійної орієнтації досліджена в роботах О. Барабанщикова, А. Дмитрієва, М. Зубалія, Г. Коваля, К. Лемківського, О. Литвина, В. Ягупова.

Аналіз і систематизація результатів наукових досліджень В. Алфімової, I. Берестецької, В. Боброва, М. Босенка, В. Борисової, Г. Волика, Т. Гнітецької, Г. Хмельницької та інших указують, що більш цілеспрямована психологопедагогічна підготовка юнаків до військової служби відбувається у військових ліцеях.

Формулювання цілей статті (постановка завдання). Військові ліцеї $\mathrm{i}$ ліцеї з посиленою військово-фізичною підготовкою мають - як заклади загальної спеціалізованої середньої освіти 3 військовим профілем на основі військовопрофесійної орієнтації, розкриття вимог до професії офіцера та належного управління психолого-педагогічною i посиленою військово-фізичною підготовкою - сприяти вирішенню таких педагогічних завдань:

Професіоналізм педагога: теоретичні й методичні аспекти. - Вип. 12. - Слов'янськ, 2020. 
- забезпечувати формування в ліцеїстів високих моральних, вольових і громадянських якостей, дисциплінованості, любові і готовності до військової служби як громадянина України та майбутнього військового професіонала;

- здійснювати підготовку фізично здорових, здатних переносити труднощі військової служби ліцеїстів, виховувати в них морально-психічні та фізичні якості, які необхідні для військової служби;

- створювати сприятливі умови для самоактуалізації ліцеїстів у провідному для них виді діяльності: навчальній, розкриття в них військовопрофесійних нахилів і здатностей.

Завдання закладів спеціалізованої середньої освіти з військовим профілем (далі - ліцеї) полягає в тому, щоб створити такі психолого-педагогічні умови та побудувати роботу керівного складу, викладачів, офіцерів-вихователів, психологів, щоб юнаки свідомо продовжували професійну освіту в інтересах Збройних сил (далі - 3С) України та обирали професію офіцера. Головною метою роботи військового ліцею має бути розумове, моральне, фізичне, культурне та моральне виховання ліцеїстів, їхня орієнтація та адаптація до життя в суспільстві, підготовка до служіння Батьківщині передусім на військовій службі.

Для цього в них слід формувати військово-професійну спрямованість за допомогою системи психолого-педагогічних, соціальних, медичних та організаційних заходів, спрямованих на формування в ліцеїстів психологічної та особистісної готовності до обгрунтованого та свідомого вибору військової професії - офіцера - відповідно до своїх схильностей, здібностей і здатностей. Отже, уся робота, що проводиться в ліцеях, має бути спрямована, на думку науковців (Тимчик, 2015), на виховання в юнаків свідомого вибору професії, офіцера, - яка має співпадати з їхніми життєвими та професійними планами $\mathrm{i}$ водночас ураховувала б потребу ЗС України у кваліфікованих військових кадрах. У зв'язку з цим важливим завданням у межах особистісно орієнтованого та контекстного навчання ліцеїстів $є$ формування в них військово-професійної орієнтації.

Мета статті - обгрунтувати педагогічні умови військово-професійної орієнтації ліцеїстів у закладах спеціалізованої середньої освіти 3 військовим профілем.

Результати дослідження. Державницький підхід до формування військово-професійної орієнтації ліцеїстів визначається в таких документах: Концепції національно-патріотичного виховання молоді; Концепції фізичного виховання в системі освіти України; Концепції патріотичного виховання молоді; наказі Міністерства оборони України № 360 від 05.06.14 року «Про затвердження 
Інструкції про організацію та проведення військово-професійної орієнтації молоді та прийому до вищих військових навчальних закладів (ВВНЗ) та військових навчальних підрозділів закладів вищої освіти (ВНП 3ВО)» (далі Інструкція) тощо.

В Інструкції поняття «військово-професійна орієнтація молоді» вживається як складова державної системи забезпечення зайнятості населення та військово-патріотичного виховання молоді, яка включає комплекс заходів соціально-психологічного та інформаційно-комунікативного характеру щодо формування військово-професійної спрямованості, поступового накопичення інформації та отримання нових даних про загальнолюдські, спеціальні здібності та професійну придатність громадянина до військової служби в ЗС України та інших військових формуваннях держави, утворених відповідно до законів України. Організація та проведення військово-професійної орієнтації молоді включає:

- військово-професійне інформування про військову професію, ВВНЗ та ВПН ЗВО, де можна ï здобути, зміст і перспективи військової служби;

- вимоги, що висуваються до особи, яка бажає отримати ту чи ту військову спеціальність;

- форми навчання й умови оволодіння різними військовими спеціальностями та можливість професійно-кваліфікаційного зростання, реалізації професійних інтересів, намірів і мотивацій особи;

- військово-професійне інформування проводиться впродовж декількох етапів: підготовчого, який починається в сім’і, дошкільному закладі та продовжується в школі до 4 - 5 класу (до 11 - 12 років); шкільного - охоплює 5 - 9 класи (до 12 - 16 років); завершального - продовжується в 10 - 11 класах (до 17 - 18 років);

- військово-професійні консультації проводяться на завершальному етапі навчання в загальноосвітніх навчальних закладах усіх типів і форм власності і вимагає участі в цьому процесі військових фахівців;

- військово-професійний відбір і добір, які проводяться командирами та фахівцями військових частин, військових комісаріатів, ВВНЗ, військових ліцеїв у процесі вивчення моральних і ділових якостей осіб, які виявили бажання вчитися у ВВНЗ (ВНП ЗВО), проведення зборів або підготовчих курсів у загальноосвітніх навчальних закладах, військових ліцеях тощо; проводиться уточнення уявлень, які мають кандидати про обрану військову професію, спеціальність, оцінюється ступінь відповідності особистісних якостей кожного кандидата вимогам, що висуває військова служба до особи, визначається його

Професіоналізм педагога: теоретичні й методичні аспекти. - Вип. 12. - Слов'янськ, 2020. 
придатність до навчання у ВВНЗ (ВНП ЗВО) та подальшої військової служби (Наказ Міністерства оборони України № 360 від 05.06.14 року).

Військово-професійна орієнтація юнака (майбутнього офіцера) - це таке професійно важливе утворення особи, яка проявляється в активному й стійкому прагненні займатися військовою діяльністю та вдосконалюватися в ній. Це усвідомлене ставлення ліцеїстів до військового обов'язку перед Батьківщиною, до своїх службових обов'язків, до обраної майбутньої військової професії. Психолого-педагогічна підтримка професійного самовизначення ліцеїстів має відбуватися постійно та «зачіпати» всі сфери їхньої життєдіяльності і проводитися комплексно не лише керівництвом військового ліцею, викладачем, педагогом-психологом, класним керівником, офіцером-вихователем, але найголовніше - соціальним середовищем ліцею.

Так, офіцер-вихователь має володіти широким духовним, психологопедагогічним і військово-професійним потенціалом, розвиненими гуманістичноспрямованими особистісними та військово-професійними якостями, бути справжнім представником держави у ЗС, шанувати загальнолюдські, національні й військові цінності, водночас формувати ці якості у своїх вихованців.

Учителі мають виховувати інтерес до навчального предмета та через його зміст і методику викладання формувати в ліцеїстів зацікавленість до військової служби, допомагати їм у професійному самовизначенні як професійного військового. До основних форм роботи педагога-психолога, який постійно має організовувати педагогічну та психологічну підтримку вихованців, належать такі: консультації, індивідуальні і групові бесіди, тренінги, які спрямовані на вирішення проблеми професійного самовизначення ліцеїстів. Функції командира взводу і класного керівника полягають у тому, щоб звертати увагу ліцеїстів не лише на особливості тієї або тієї професії, але й на важливі професійні особистісні характеристики, розвиток яких вимагає певної кількості часу і може починатися вже в підлітковому віці. Але військово-професійна орієнтація передбачає взаємодію двох систем: 1) особистість як складна саморегулювальна система; 2) система педагогічних умов, які сприяють військово-професійному самовизначенню ліцеїста.

У зв'язку з цим до основних педагогічних умов військово-професійної орієнтації ліцеїстів необхідно віднести такі:

Перша педагогічна умова - це військово-патріотичне виховання ліцеїстів як основи формування цінностей і мотивів майбутньої військовопрофесійної діяльності, яке є складовою патріотичного виховання в державі, у процесі якого формуються цінності та мотивація майбутньої військово- 
професійної діяльності, інтелектуальна, морально-психологічна і фізична готовність ліцеїстів до захисту Вітчизни. Основна мета - це формування цінностей: патріотичних почуттів і ставлень, виховання справжнього ідеалу служіння народові, готовності до трудового та героїчного подвигів в ім'я процвітання Української держави. Воно покликане формувати людину-патріота, виробляти глибоке розуміння громадянського обов'язку, готовність у будь-який час стати на захист Батьківщини, бажання оволодівати військовими знаннями, спонукати до фізичного вдосконалення, а також вивчення бойових традицій і героїчних сторінок історії українського народу (Ягупов, 2000).

Військово-патріотичне виховання включає також і підготовку юнаків до військової служби. У Концепції нового патріотизму незалежної України багато уваги акцентується, на думку В. Ткаченко, на національно усвідомленому ставленні до Батьківщини, що передбачає іiі захист у лавах 3С: «Армія $\epsilon$ сконцентрованою вольовою силою держави, оплотом Батьківщини, організацією честі, самовідданості й служіння - таке відчуття має бути передане вихователем дитині» (Ткаченко, 2008).

3 педагогічного погляду, військово-патріотичне виховання ліцеїстів на основі узагальнення наукових джерел із патріотичного виховання (А. Афанасьєв, I. Бех， М. Боришевський， С. Карпенчук， I. Підласий, В. Ягупов) вважаємо цілеспрямованим педагогічним процесом системного, комплексного, контекстного, гуманного та водночас всебічного впливу військових педагогів, державних і громадських організацій на свідомість, підсвідомість, емоційнопочуттєву та ціннісно-мотиваційну сфери ліцеїстів, формування в них позитивного ставлення до майбутньої військової професії як українських громадян і майбутніх військових професіоналів, а також на психологію колективу ліцеїстів для формування в них високих громадянських, моральних, військово-професійних, соціально-психологічних, фізичних та інших якостей, необхідних для успішного продовження професійної освіти у ВВНЗ та подальшої військової служби як військового професіонала.

Для цього в ліцеї має бути сформована педагогічна система військовопатріотичного виховання ліцеїстів, яка має забезпечувати досягнення такого рівня їхньої патріотичної вихованості, який дозволятиме їм якісно й у повному обсязі виконувати в майбутньому військовий обов'язок, відчувати себе справжнім громадянином Української держави, відповідальним за творчий розвиток найкращих бойових традицій українського народу та його війська, зіставляти свою поведінку та військово-професійну діяльність із вимогами національного та військового етикету тощо. Систему військово-патріотичного

Професіоналізм педагога: теоретичні й методичні аспекти. - Вип. 12. - Слов’янськ, 2020. 
виховання (у педагогічному розумінні) можна вважати науково обгрунтованим феноменом педагогічної взаємодії між вихователями (командирами та начальниками), а також цивільними фахівцями (викладачами, психологами), які можуть брати участь у вихованні ліцеїстів, і вихованцями (ліцеїстами, майбутніми офіцерами), яка створена на українознавчій основі, на засадах національно-історичних, бойових та інших традицій i звичаїв українського народу та його 3С, який інтегрований у систему національного, громадянського та патріотичного виховання громадян нашої держави.

Мотивація, як виокремлена наукова проблема, $\epsilon$ одною 3 ключових у професійній психології та педагогіці. Науковці всього світу присвятили безліч своїх праць дослідженню рушійних, тобто мотивації, що спонукають фахівця до професіоналізації. Мотивацію майбутньої трудової діяльності А. Маслоу обгрунтував як концепцію потреб від «нижчих» матеріальних до «вищих» духовних (Маслоу, 1999). У великому тлумачному словнику термін «мотив» визначено як підстава, привід для якої-небудь дії, вчинку; причина (Бусел, 2004). Натомість І. Джирдар'ян розглядає мотивацію як механізм, що визначає напрямок і засіб здійснення конкретних форм діяльності (Джирдарьян, 1974). Власне в такому контексті розуміємо в нашому дослідженні.

Професійна мотивація передбачає наявність мотивів, цілей та інтересів до майбутньої професії, водночас ураховуються індивідуальні схильності та здатності ліцеїстів до військово-професійної діяльності. Це рушійна сила, процес спонукання ліцеїста на досягнення певних цілей у навчальній діяльності, а в перспективі й професійних цілей та подальшому - кар'єрного зростання. Науковці по-різному обгрунтовують рушійні сили розвитку особистості. Так, В. Ягупов визначає такі рушійні сили: рівень розвиненості особистості та i ідеали, життєві цінності й настанови; потреби, мотиви, мотивації особистості та моральний обов’язок; життєві домагання особистості та їі можливості; спадкові данні та потреби вихованця; особливості протікання нервово-психічних процесів особистості тощо. Він зазначає, що мотивація навчально-пізнавальної діяльності складається з сукупності певних мотивів для досягнення в ній успіхів, а мотив навчально-пізнавальної діяльності - це намагання учня досягти певного рівня розвиненості в учінні та професійній діяльності, в основі якої лежать глибокі, міцні та різноманітні загальнонаукові та професійні знання, навички та вміння (Ягупов, 2002).

Н. Волкова зазначає, що методи стимулювання і мотивації спрямовані на формування позитивних мотивів, які стимулюють пізнавальну активність i сприяють збагаченню учнів навчальною інформацією. До цієї категорії належать 
методи формування пізнавальних інтересів вихованців і методи обов'язку й відповідальності. На іiі думку, методи формування пізнавальних інтересів учнів будуть мати рушійну силу, створювати позитивний настрій, зацікавленість, а харизматичний, емоційний викладач зможе зацікавити їх окремою темою, питанням, розділом (Волкова, 2007).

До завдання формування мотивації до навчально-пізнавальної діяльності та до подальшої військової кар'єри ліцеїстів необхідно підходити з урахуванням вікових особливостей вихованців, їхніх індивідуальних психологічних характеристик. Одним із мотивів, притаманних нашій категорії юнаків (15 - 17 років), є мотив ідентифікації з іншою людиною. У його основі лежить прагнення стати схожим на свого героя, кумира або людину, яка для нього є авторитетною: батька, начальника військового ліцею, керівного складу, офіцера-вихователя, викладача та ін. Посилений вплив на мотив майбутнього військового фахівця мають кінофільми як художні, так і документальні військово-патріотичного спрямування. Завдяки ним підвищується потенціал юнака до вибору майбутньої професії офіцера, його прагнення діяти і працювати як герой кінофільму. У цьому віці юнаку притаманний належний рівень сформованої оптації, спрямований на навчання в профільних ВВНЗ (Брижатий, 2013).

Ще однією передумовою до вибору професії стають особистісні, соціальні та професійні цінності, які підкріплені порадами батьків, друзів, викладачів, офіцерів-вихователів і стають у подальшому, як правило, підвалиною вибору військової професії. Юнак ставить перед собою вибір престижної професії, він виходить з уявлень наявної, так званої сучасної «моди» на професію. На жаль, негативний досвід минулих років свідчить про те, що велике значення у виборі майбутньої професії мало поняття престижу. Так, у 40 - 60 роки престижно було опановувати інженерні та будівельні професії, у 70 - 80 роках - гуманітарні, у 90-ті роки розпочалась комерційна діяльність, професії у сфері обслуговування, у 2000 році - професії економічного напряму та юридичні, після початку подій 2014 року на сході нашої держави військова професія стала необхідністю. Обравши майбутню професію, - бути військовим, - юнак виявляє бажання служити Батьківщині. Це спонукає його до інтенсивного опанування навчальних дисциплін і заняття спортом та фізичною культурою. Кінцева мета цього мотиву - стати офіцером і утвердити себе в соціумі (Брижатий, 2013).

По завершенні навчання вихованець ліцею повинен мати сформоване уявлення про військову службу та сталу мотивацію становлення військовим професіоналом.

Друга педагогічна умова - це формування культури навчальної 
діяльності в ліцеїстів. Проблема активізації навчально-пізнавальної діяльності ліцеїстів безпосередньо зумовлена культурою їхньої навчальної діяльності. Для цього вони мають вирішувати такі завдання:

- чітке визначення цілей своєї навчальної діяльності, усвідомлення іiї цінностей, смислу та результатів;

- опанування традиційними та сучасними прийомами, способами та засобами навчальної діяльності, наприклад, засобами IКТ, дистанційного навчання тощо;

- оволодіння прийомами, способами та засобами самомотивування, самодетермінації, самоорганізації, самокорегування та самооцінювання своєї навчальної діяльності, які будуть украй необхідні для продовження професійної освіти у ВВНЗ.

Для цього педагоги мають використовувати такі методики навчання, які створили б максимальні можливості та сприятливі умови для прояву ініціативності, самостійності і творчості ліцеїстів, для якісного контролю за навчально-пізнавальною діяльністю. Якість і результативність навчальнопізнавальної діяльності ліцеїстів залежить від умінь педагога планувати, організовувати та цілеспрямовано управляти їхньою пізнавальною діяльністю.

3 цією метою пропонуємо такі дії: опора на психолого-педагогічні знання та особливості освітнього процесу; поєднання в методиці викладання основ вікової та педагогічної психології і дидактики; створення авторської методики викладання на основі використання системи психологічних і дидактичних знань; урахування дидактичних умов, зокрема змісту дисципліни та завдань кожного навчального заходу, завдяки яким організовується пізнавальна діяльність ліцеїстів.

Сучасна дидактика вимагає від суб'єктів учіння не лише розуміти, запам'ятовувати й відтворювати отримані знання, але й найголовніше - уміти ними оперувати, творчо розвивати та успішно застосовувати в професійній діяльності. Досягненню цієї мети сприяють методи активізації навчальнопізнавальної діяльності ліцеїстів, які спрямовані на формування в них творчого контекстного мислення і здатності кваліфіковано розв'язувати різноманітні навчальні, а інколи й квазіпрофесійні завдання. Використання цих методів забезпечує тісний зв'язок теорії з військовою практикою, формування творчого стилю мислення ліцеїстів, рефлективності: самосвідомості й саморегуляції навчальної діяльності, створення атмосфери співробітництва, формування творчих навичок і вмінь міжособистісної взаємодії. 
В. Ягупов визначає методи активізації навчально-пізнавальної діяльності тих, хто вчиться, як «сукупність прийомів і способів психолого-педагогічного впливу на учнів, що (порівняно з традиційними методами навчання) насамперед спрямовані на розвиток у них творчого самостійного мислення, активізацію пізнавальної діяльності, формування творчих навичок й умінь нестандартного вирішення певних професійних проблем і вдосконалення навичок професійного спілкування». Він поділяє їх на імітаційно-ігрові (метод інсценування, ділові ігри) та неігрові (аналіз конкретної ситуації, мозковий штурм, метод круглого столу); неімітаційно-лекційні (лекція-бесіда, лекція-аналіз конкретної ситуації, лекція з використанням техніки зворотного зв'язку, лекція-консультація, лекціяпрес-конференція, лекція із заздалегідь запланованими помилками); нетрадиційні семінарські (практичні) заняття (семінар-дискусія, семінарвзаємонавчання); інтелектуальна розминка; сократична бесіда (Ягупов, 2002).

Імітаційні методи активізації навчально-пізнавальної діяльності ліцеїстів пов'язані 3 імітацією (наслідуванням) певного процесу, явища, системи управління та сприяють розвитку професійних, організаційних та управлінських умінь і навичок. Їхнє застосування в підготовці ліцеїстів дозволяє моделювати різні професійні ситуації, формувати в ліцеїстів уміння й навички, способи та досвід творчої навчальної діяльності.

Неімітаційні методи активізації навчально-пізнавальної діяльності реалізуються завдяки проблематизації змісту навчального матеріалу. Застосування їх під час підготовки ліцеїстів сприяє активізації їхнього мислення, що є запорукою усвідомлення й оволодіння знаннями (Ягупов, 2002).

Активні методи навчання дають можливість активізувати в ліцеїстів творчу навчальну діяльність, стимулювати їхній емоційно-інтелектуальний потенціал, формувати в них культуру навчальної діяльності, які необхідні в майбутньому для набуття військово-професійної освіти.

Отже, можна стверджувати про доцільність та ефективність використання активних форм і методів навчання в процесі підготовки ліцеїстів до майбутньої військової професії. Це дозволяе їх «озброїти» надійними знаннями, навичками та вміннями, адаптаційними механізмами до екстремальних чинників майбутньої військово-професійної діяльності, забезпечувати стійкість емоційновольової сфери, формування пошуково-дослідницької компетентності як творчого учня та здатність корегувати свою навчальну діяльність згідно 3 певними сталими та ситуаційними аспектами навчальної діяльності.

Але водночас не можна ігнорувати традиційні методи навчання, бо лише комплексний розгляд і творче застосування традиційних і нетрадиційних методів 
навчання сприяють успішному досягненню мети педагогічного процесу підготувати ліцеїстів до набуття військового фаху. Головна відмінність традиційних методів навчання від активних полягає в тому, що під час традиційного навчання в ліцеї головним завданням є передача готових знань від викладача до ліцеїста, який має їх запам'ятовувати та відтворювати, активні ж методи навчання спрямовані на творче самостійне оволодіння вихованцями знаннями, уміннями та навичками в процесі їхньої активної розумової i навчальної діяльності.

Зазначимо, що військово-професійна орієнтація юнаків - складний багатоетапний процес усвідомленого вибору ліцеїстами військової професії. Перш ніж зробити підтримку ліцеїста в професійному самовизначенні, необхідно усвідомити мету і зміст надання допомоги, чітко уявляти перспективи та обмеження розвитку ліцеїста залежно від вибору професії і подальшої професійної освіти. Недостатньо дати рекомендації вихованцю, яка професія йому краще підходить, а необхідно створювати педагогічні умови, що стимулюють його становлення як особистості та сприяють військовопрофесійній орієнтації.

Висновки. Так, приходимо до висновку, що формування в ліцеїстів військово-професійних орієнтацій буде ефективніше, якщо дотримуватись таких педагогічних умов:

- постійно поглиблювати в ліцеїстів інтерес до класної та позакласної роботи 3 військово-патріотичного виховання на основі традицій, звичаїв, духовних надбань українського народу;

- необхідно виховувати в ліцеїстів національну самосвідомість, налаштованість на осмислення моральних, культурних і військово-професійних цінностей, історії, системи вчинків, які мотивуються вірою, волею, усвідомленням своєї відповідальності за своє професійне майбутнє;

- системно здійснювати виховання в учнів громадянської позиції, патріотичних ставлень до власного професійного буття, вивчення та популяризацію історії українського війська, збереження і пропаганду історикокультурної спадщини українського народу, поліпшення військово-патріотичного виховання ліцеїстів, формування готовності до захисту Вітчизни;

- формувати моральні якості та цінності захисника Батьківщини, військовий етикет, розвивати мотивацію навчальної діяльності та набуття військового фаху; 
Педагогічні умови військово-професійної оріснтації ліцеїстів закладів спеціалізованої середньої освіти з військовим профілем

- формувати пізнавальну мотивацію та навчальну активність ліцеїстів, підтримувати їхню зацікавленість у смислі, цінностях і змісті навчальної діяльності;

- творчо використовувати різні методи активізації навчально-пізнавальної діяльності ліцеїстів, які сприяють свідомому оволодінню ними знаннями, уміннями й навичками, викликають інтерес до майбутньої військової професії, формують сукупність професійно важливих якостей для військовослужбовця.

3 огляду на це подальший науковий пошук буде спрямований на педагогічне моделювання військово-професійної орієнтації ліцеїстів і розроблення комплексної методики іï формування.

\title{
СПИСОК ВИКОРИСТАНИХ ДЖЕРЕЛ
}

1. Брижатий, С. I. (2013). Врахування мотиваційних чинників у структурі підготовки майбутніх офіцерів інженерних військ. Вісник Національного університету оборони Украӥни, 3(34), 19-25.

2. Бусел, В. Т. (2004). Великий тлумачний словник сучасної української мови. Київ, Ірпінь, Україна: ВТФ «Перун».

3. Волкова, Н. П. (2007). Педагогіка. Київ, Україна: Академвидав.

4. Джирдарьян, И. А. (1974). О месте потребностей, эмоций и чувств в мотивации личности. Теоретические проблемы психологи. (С. 145-169). Москва, Российская Федерация: Наука, Е. В. Шорохова.

5. Маслоу, А. (1999). Новые рубежи человеческой природы. Москва, Российская Федерация: Смысл.

6. Наказ Міністерства оборони України № 360 від 05.06.14 року «Про затвердження Інструкції про організацію та проведення військово-професійної орієнтації молоді та прийому до вищих військових навчальних закладів та військових навчальних підрозділів закладів вищої освіти». Взято з https://zakon.rada.gov.ua/laws/show/z0704-14

7. Тимчик, М.В. (2015). Патріотичне виховання старших підлітків у прочесі фізкультурно масової роботи. (Дис. канд. пед. наук). Київ, Україна: Київський Національний університет.

8. Ткаченко, В. М. (2008). Патріотизм. Енцииклопедія освіти. Київ, Україна.

9. Ягупов, В. В. (2000). Військове виховання: історія, теорія і методика. Київ, Україна. 10. Ягупов, В. В. (2002). Педагогіка. Київ, Україна: Либідь.

\section{PEDAGOGICAL CONDITIONS OF MILITARY AND PROFESSIONAL ORIENTATION OF LYCEUM STUDENTS OF SPECIALIZED SECONDARY EDUCATION INSTITUTIONS WITH MILITARY PROFILE}

\author{
Vasyl Yagupov \\ Doctor of Pedagogical Sciences, \\ Professor of Ivan Chernyakhovsky National University of Defense of Ukraine, \\ Kyiv, Ukraine \\ ORCID ID 0000-0002-8956-3170 \\ yagupow1957@gmail.com
}

Професіоналізм педагога: теоретичні й методичні аспекти. - Вип. 12. - Слов'янськ, 2020. 
В. ЯГУПОВ, К. СРГІДЗЕЙ

Педагогічні умови військово-професійної оріснтації ліцеїстів закладів спеціалізованої середньої освіти з військовим профілем

\title{
Kseniia Yerhidzei \\ Applicant, Head of Research Laboratory, Ivan Chernyakhovsky National Defense University of Ukraine, Kyiv, Ukraine \\ ORCID ID 0000-0003-4634-133X \\ ergidzey@ukr.net
}

\begin{abstract}
The article is devoted to the relevant issue - military and professional orientation of lyceum students of specialized secondary education institutions with military profile lyceum. The results of generalizing the scientific findings made by scientists who solve the problem of military and professional orientation of young people have been worked out. The main pedagogical conditions of military and professional orientation of lyceum students are defined, which should include military-patriotic education of young people, formation of values and motivation of future military and professional activities of lyceum students, as well as formation of culture of educational and cognitive activity of lyceum students.
\end{abstract}

The article identifies the necessary components of the patriotic education of the lyceum, defines its types and forms, which should be used in modern conditions in the lyceum. The values are considered to be a key factor in the military and professional orientation of the lyceum students, which is the basis of their motivation sphere for the future military-professional career. Motivation is one of the main conditions for successful educational and future military-professional activities of lyceum students. It also promotes the culture of the lyceum's educational activities.

The issue of activation of educational and cognitive activity of lyceum students is directly caused by the culture of their educational activities. For this purpose the tasks that they must do are defined: to clearly define the goals of their educational activity, awareness of its values, meaning and results; to master traditional and modern techniques, methods and means of educational activities; to master the techniques, methods and means of self-motivation, self-determination, self-organization, self-correction and self-evaluation of their educational activities, which are indispensable for further professional education in a higher military educational establishment.

The methods of activation of educational and cognitive activities of lyceum students are determined. They are divided into: imitation - game and non-game; non-imitative - lectures; nontraditional seminars (tutorials); intellectual warm-up; Socratic dialogue. Active teaching methods give the opportunity to activate creative educational activities of lyceum students, to stimulate their emotional and intellectual potential, to form their culture of educational activity, which is necessary in the future for the acquisition of military and professional education.

It should be noted that the military and professional orientation of young people is a complex multi-stage process of conscious choice by the military lyceum.

Key words: pedagogical conditions; military and professional orientation; military and patriotic education; motivation; values; educational and cognitive activity; readiness for service in the army; lyceum.

\section{REFERENCES}

1. Bridzhaty, E. I. (2013). Taking into account motivational factors in the structure of training of future officers of engineering troops. Visnyk Natsionalnoho universytetu oborony Ukrayiny, 3(34), $19-25$.

2. Busel, V. T. (2004). A great explanatory dictionary of modern Ukrainian. Kiev, Irpin, Ukraine: VTF "Perun".

3. Volkova, N. P. (2007). Pedagogy. Kiev, Ukraine: Academvydav. 


\section{В. ЯГУПОВ, К. СРГІДЗЕЙ}

Педагогічні умови військово-професійної орієнтації ліцеїстів закладів спеціалізованої середньої освіти з військовим профілем

4. Dzhirdaryan, I. A. (1974). On the place of needs, emotions and feelings in the motivation of the individual. Teoreticheskiye problemy psikhologii. (Pp. 145-169). Moscow, the Russian Federation: Nauka, E.V. Shorokhova,.

5. Maslow, A. (1999). New frontiers in human nature. Moscow, the Russian Federation: Smysl.

6. Order of the Ministry of Defense of Ukraine No. 360 of June 5, 14, "On Approval of the Instruction on the Organization and Conduct of Military-Professional Orientation of Youth and Admission to Higher Military Educational Institutions and Military Educational Units of Higher Education Institutions". Retrieved from https://zakon.rada.gov.ua/laws/show/z0704-14

7. Tymchyk, M. V. (2015). Patriotic upbringing of older adolescents in the process of physical education. (PhD Dissertation). Kiev, Ukraine: Kyyivskyi Natsionalnyi universytet.

8. Tkachenko, V. M. (2008). Patriotism. Encyclopedia of Education. Kyiv, Ukraine.

9. Yagupov, V. V. (2000). Military education: history, theory and methodology. Kyiv, Ukraine.

10. Yagupov, V. V. (2002). Pedagogy. Kyiv, Ukraine: Lybid.

Матеріали надійшли до редакції 07.04.2020 p. 